\title{
Assessing the impact of rice import quota policy on the Malaysian rice sector
}

\begin{abstract}
After the food crisis in 2008, the Malaysian government reintroduced their efforts to reach rice self-sufficiency and to stabilize domestic prices by using a rice import quota of 700,000 tons per year. Though with the emergence of trade liberalization and regional agreements, Malaysian government interventions should be limited. Therefore, this article attempts to assess the impact of removing the rice import quota on the rice sector in Malaysia using a system dynamics model. The simulated results showed that due to developing rice-based industry in Malaysia and its effects on the rice market situation, the rice import quota might have a negative impact on increasing farmers' income, more affordable prices for consumers, and diversification of food in Malaysia.
\end{abstract}

Keyword: Import quota; Malaysia; Rice sector; System dynamics modeling 